\title{
In vitro assessment of hepatoprotective agents against damage induced by acetaminophen and $\mathrm{CCl}_{4}$
}

\author{
Liliana Torres González , Noemí Waksman Minsky², Linda Elsa Muñoz Espinosa', Ricardo Salazar Aranda², \\ Jonathan Pérez Meseguer ${ }^{2}$ and Paula Cordero Pérez ${ }^{* *}$
}

\begin{abstract}
Background: In vitro bioassays are important in the evaluation of plants with possible hepatoprotective effects. The aims of this study were to evaluate the pretreatment of HepG2 cells with hepatoprotective agents against the damage induced by carbon tetrachloride $\left(\mathrm{CCl}_{4}\right)$ and paracetamol (APAP).

Methods: Antioxidative activity was measured using an assay to measure 2,2-diphenyl-1-picrylhydrazyl (DPPH) free radical scavenging. The in vitro hepatotoxicity of $\mathrm{CCl}_{4}$ and APAP, and the cytotoxic and hepatoprotective properties of silymarin (SLM), silybinin (SLB), and silyphos (SLP) were evaluated by measuring cell viability; activities of aspartate aminotransferase (AST), alanine aminotransferase (ALT), and lactate dehydrogenase (LDH); total antioxidant capacity (TAOXC); and reduced glutathione (GSH), superoxide dismutase (SOD), and lipid peroxidation (malondialdehyde (MDA) levels).

Results: Only SLB and SLM showed strong antioxidative activity in the DPPH assay $(39.71 \pm 0.85 \mu \mathrm{g} / \mathrm{mL}$ and $14.14 \pm 0$. $65 \mu \mathrm{g} / \mathrm{mL}$, respectively). $\mathrm{CCl}_{4}$ induced time- and concentration-dependent changes. $\mathrm{CCl}_{4}$ had significant effects on cell viability, enzyme activities, lipid peroxidation, TAOxC, and SOD and GSH levels. These differences remained significant up to an exposure time of $3 \mathrm{~h}$. APAP induced a variety of dose- and time-dependent responses up to $72 \mathrm{~h}$ of exposure. SLM, $\mathrm{SLB}$, and SLP were not cytotoxic. Only SLB at a concentration of $100 \mu \mathrm{g} / \mathrm{mL}$ or $150 \mu \mathrm{g} / \mathrm{mL}$ significantly decreased the enzyme activities and MDA level, and prevented depletion of total antioxidants compared with $\mathrm{CCl}_{4}$.
\end{abstract}

Conclusions: $\mathrm{CCl}_{4}$ was more consistent than APAP in inducing cell injury. Only SLB provided hepatoprotection. AST, LDH, and MDA levels were good markers of liver damage.

Keywords: Hepatoprotective, HepG2 cell line, Acetaminophen, Carbon tetrachloride, Silybinin, Silyphos, Silymarin

\section{Background}

Medicinal plants with hepatoprotective activity contain a large number of bioactive molecules. The identification of these molecules contained in a biomass complex requires careful selection and execution of appropriate bioassays during the various stages of the research process [1]. In vitro bioassays are important in the evaluation of plants with possible hepatoprotective effects.

Human hepatoma cell lines have been proposed as an alternative to human hepatocytes for in vitro models of

\footnotetext{
* Correspondence: paucordero@yahoo.com.mx

'Liver Unit, Gastroenterology Service, Department of Internal Medicine, University Hospital "Dr. José E. González", Av. Gonzalitos \#235 Col. Mitras Centro C.P., 64460 Monterrey, Nuevo León, Mexico

Full list of author information is available at the end of the article
}

normal liver cells. The potential advantages of hepatoma cells are that, as an immortalized cell line, they are readily available in large quantities, they are easy to maintain because they can be cryopreserved, and their drugmetabolizing enzyme activities do not decrease in cultivation, as happens in primary cultures of human hepatocytes [2]. However, an obvious disadvantage is that the mechanisms underlying drug metabolism and toxicity may be abnormal in transformed cells. Despite these issues, the HepG2 hepatoma cell line is used widely in studies of liver function, metabolism, and drug toxicity [3, 4]. HepG2 cells also possess many of the biochemical and morphological characteristics of normal hepatocytes [5]. Because they retain many characteristics of normal liver cells, these cells 
are used in studies to determine whether medicinal plants have hepatoprotective activities [6,7].

One hepatoprotective agent used widely in the treatment of various liver disorders, such as hepatitis or fatty infiltration caused by alcohol or toxins, is the standardized extract of Silybum marianum, known as milk thistle or silymarin (SLM) [8-11]. It is a complex mixture of the flavonolignans silybinin (SLB), silychristin, silydianin, and isosilybin. SLB, a polyphenolic molecule, is the major component of SLM and is responsible for its pharmacological activity $[12,13]$. SLM is poorly absorbed, although the bioavailability of SLB is higher than that of phosphatidylcholine (silyphos (SLP)) [14, 15].

The major inducers of hepatic damage used when evaluating hepatoprotective activity are paracetamol (acetaminophen, APAP) and carbon tetrachloride $\left(\mathrm{CCl}_{4}\right)$. However, there are few reports on their use and in vitro characteristics $[6,7,16]$. The mechanisms responsible for the in vivo liver toxicity of both compounds are complex and involve several cell types $[17,18] . \mathrm{CCl}_{4}$ undergoes metabolic activation in a cytochrome P-450dependent step to produce free radicals, which can initiate lipid peroxidation. The toxicity induced by $\mathrm{CCl}_{4}$ in vivo and in cultured hepatocytes involves stimulation of lipid peroxidation, which is detected as an increase in malondialdehyde (MDA) formation [19]. APAP is metabolized mainly in the liver to excretable glucuronide and sulfate conjugates. However, the hepatotoxicity of APAP has been attributed to the formation of toxic metabolites, which occurs when APAP is activated by hepatic cytochrome P-450 [20] to a highly reactive metabolite Nacetyl-P-benzoquinoneimine (NAPQI) [21]. NAPQI is initially detoxified by conjugation with reduced glutathione (GSH) to form mercapturic acid. However, when its rate of formation exceeds the rate of detoxification by GSH, NAPQI oxidizes tissue macromolecules such as lipids and $-\mathrm{SH}$ group proteins, and calcium homeostasis is altered by depletion of GSH [22].

The aims of this study were to evaluate the hepatoprotective activities of SLM, SLB, and SLP against liver damage induced by APAP and $\mathrm{CCl}_{4}$ in the HepG2 cell line.

\section{Methods}

\section{General}

SLB, SLM, 2,2-diphenyl-1-picrylhydrazyl free radical (DPPH), 3-(4,5-dimethylthiazol-2-yl)-2,5-diphenyl-2H-tetrazolium bromide (MTT), and $\mathrm{CCl}_{4}$ (99.9\%) were purchased from Sigma-Aldrich Chemical Co. (St Louis, MO, USA). SLP was purchased from Medix, S.A. de C.V. (México City, D.F. México), and dimethyl sulfoxide (DMSO) was purchased from ACS Research Organics (Cleveland, $\mathrm{OH}$, USA). Total antioxidant capacity (TAOxC), GSH, superoxide dismutase (SOD), and thiobarbituric acid reactive substances were purchased from Kit OXItek (Buffalo, NY,
USA). Dulbecco's modified Eagle's medium advanced (DMEMA) with and without phenol red, fetal bovine serum, trypsin $0.25 \%(1 \times)$, penicillin G $(100 \mathrm{IU} / \mathrm{mL})$, streptomycin $(100 \mu \mathrm{g} / \mathrm{mL})$, and phosphate-buffered saline (PBS) were purchased from Gibco Invitrogen (Carlsbad, CA, United States). Aspartate aminotransferase (AST), alanine aminotransferase (ALT), and lactate dehydrogenase (LDH) activities were measured using an ILab 300 Plus chemistry analyzer (Instrumentation Laboratory, Bedford, MA, USA).

Measurement of free radical reduction using the DPPH assay Antioxidant activity was measured as described previously by Salazar et al. [23]. Briefly, the hepatoprotective agents were dissolved in ethanol to obtain stock solutions $(1000 \mu \mathrm{g} / \mathrm{mL})$, from which serial dilutions were made. Diluted solutions $(0.5 \mathrm{~mL}$ of each) were mixed with $0.5 \mathrm{~mL}$ of $125 \mu \mathrm{M} \mathrm{DPPH}$ and allowed to react for $30 \mathrm{~min}$. Ultraviolet absorbance was recorded at $517 \mathrm{~nm}$ (Multiskan EX; Thermo/LabSystems, Vantaa, Finland). The experiment was performed in triplicate and the average absorption was recorded for each concentration. The same procedure was followed for the quercetina (positive control).

\section{Cell culture}

HepG2 human liver hepatoma cells were obtained from the Laboratory of Liver, Pancreas and Motility, Department of Experimental Medicine, Faculty of Medicine, Universidad Nacional Autónoma de México, México City, DF, México. Cells were grown in standard conditions: supplemented DMEMA at $37{ }^{\circ} \mathrm{C}$ in a humidified $5 \%$ carbon dioxide atmosphere. When the cells reached $80-90 \%$ confluence, they were trypsinized and plated at 30,000 cells per well in a 96-well microplate, $1 \times 10^{6}$ cells per well in six plates, or $5 \times 10^{7}$ cells per well in a single dish, depending on the determination. The cells were used after attachment.

\section{$\mathrm{CCl}_{4}$-induced toxicity in HepG2 cells}

HepG2 cells were incubated in medium or treated with the toxic agent $\left(20 \mathrm{mM}, 30 \mathrm{mM}\right.$, or $40 \mathrm{mM} \mathrm{CCl}_{4}$ in $0.05 \%$ DMSO) for $1,1.5,2$, or $3 \mathrm{~h}$. The evaluation assays were performed using standard methods as described in the "Evaluation assays" section below.

\section{APAP-induced toxicity in HepG2 cells}

HepG2 cells were treated with the toxic agent $(2 \mathrm{mM}$, $4 \mathrm{mM}$, or $8 \mathrm{mM}$ APAP) or incubated with medium only for $12,24,48$, or $72 \mathrm{~h}$. The evaluation assays were performed using standard methods as described in the "Evaluation assays" section below. 


\section{Effects of SLM, SLB, and SLP on HepG2 cells}

The cytotoxic effects of SLM, SLB, and SLP were measured in HepG2 cells exposed for $12 \mathrm{~h}$ to compounds at 10,100 , or $150 \mu \mathrm{g} / \mathrm{mL}$ in supplemented DMEMA. HepG2 cells in medium only were used as a negative control. The evaluation assays were performed using standard methods as described in the "Evaluation assays" section below.

\section{In vitro assay to identify hepatoprotective effects}

The hepatoprotective effects of SLM, SLB, and SLP on HepG2 cells were measured as follows. Normal control cells were incubated with DMEMA in DMSO $(0.05 \% \mathrm{v} / \mathrm{v})$ for $12 \mathrm{~h}$. For toxic treatment, cells were incubated with DMEMA in DMSO $(0.05 \% \mathrm{v} / \mathrm{v})$ for $12 \mathrm{~h}$ and then treated with DMEMA with $40 \mathrm{mM} \mathrm{CCl}_{4}$ for $1.5 \mathrm{~h}$. For SLM treatment, cells were incubated with DMEMA with SLM at 10, 100 , or $150 \mu \mathrm{g} / \mathrm{mL}$ for $12 \mathrm{~h}$ and then treated with $40 \mathrm{mM}$ $\mathrm{CCl}_{4}$ for $1.5 \mathrm{~h}$. For SLB treatment, cells were incubated with DMEMA with SLB at 10, 100, or $150 \mu \mathrm{g} / \mathrm{mL}$ for $12 \mathrm{~h}$ and then treated with $40 \mathrm{mM} \mathrm{CCl}$ for $1.5 \mathrm{~h}$. For SLP treatment, cells were incubated with DMEMA with SLP at 10,100 , or $150 \mu \mathrm{g} / \mathrm{mL}$ for $12 \mathrm{~h}$ and then treated with $40 \mathrm{mM} \mathrm{CCl} 4$ for $1.5 \mathrm{~h}$. The evaluation assays were performed using standard methods as described in the "Evaluation assays" section below.

\section{Evaluation assays}

Each assay was performed in triplicate and the experiments were repeated three times.

\section{Cell viability assay}

Cell viability was assessed using the MTT reduction assay with slight modifications [24]. This colorimetric assay involves the conversion of MTT to a purple formazan derivative by mitochondrial succinate dehydrogenase, which is present only in viable cells. The cells were treated with SLM, SLB, SLP, and/or the toxic agent. The medium was then removed and the cells were then incubated with MTT $(0.5 \mathrm{mg} / \mathrm{mL})$ for $2 \mathrm{~h}$, after which the formazan crystals were dissolved with $200 \mu \mathrm{L} /$ well of DMSO. Absorbance was measured at $570 \mathrm{~nm}$ (Multiskan EX; Thermo/ LabSystems, Vantaa, Finland). Viability was defined as the ratio of the absorbance of treated cells to that of untreated control cells and is expressed as a percentage.

\section{Measurement of AST, ALT, and LDH activities}

AST, ALT, and LDH activities were measured using an ILab 300 Plus system and Instrumentation Laboratory assay kits. HepG2 cells were treated with SLM, SLB, SLP, and/or the toxic agent. The supernatant was removed from the wells, and the enzyme activities were measured immediately. The results are expressed as IU/L.

\section{Measurement of TAOxC}

TAOxC was measured in lysed HepG2 cells using an Antioxidant Assay kit from Cayman Chemical Company (Ann Arbor, MI, USA). The kit is based on the ability of antioxidants in the sample to inhibit the oxidation of 2,2'-azino-bis-3-ethylbenzothiazoline (ABTS) to $\mathrm{ABTS}^{+}$ by metmyoglobin. HepG2 cells were treated with SLM, SLB, SLP, and/or the toxic agent. After treatment, the adherent cells were scraped off and suspended in $5 \mathrm{mM}$ potassium phosphate, $\mathrm{pH} 7.4$, containing $0.9 \%$ sodium chloride and $0.1 \%$ glucose, sonicated, and placed on ice. The supernatant of the lysed cells was used to measure TAOxC. Absorbance in the well was measured after $5 \mathrm{~min}$ at a wavelength of $405 \mathrm{~nm}$ on a microplate reader (Multiskan EX; Thermo/LabSystems, Vantaa, Finland). The results are expressed as millimoles of antioxidant.

\section{Measurement of GSH level}

GSH level was quantified using a Glutathione Assay kit from Cayman Chemical Company. The assay kit is based on the enzymatic 5,5'-dithiobis-2-(nitrobenzoic acid) (DTNB) disulfide dimer-oxidized GSH reductase recycling method. After treatment, the medium was removed from the wells, and the adherent cells were scraped off and suspended in $0.5 \mathrm{~mL}$ of $50 \mathrm{mM}$ phosphate, $\mathrm{pH} 6.5$, containing $1 \mathrm{mM}$ ethylenediaminetetraacetic acid, sonicated, and placed on ice. The supernatant of lysed cells was used to measure GSH level. Absorbance of the yellow product in the well was measured at a wavelength of $405 \mathrm{~nm}$ on a microplate reader at $5 \mathrm{~min}$ intervals for $30 \mathrm{~min}$. The total GSH activity was measured using the kinetic method from a standard curve of GSH. The results are expressed as micromoles of GSH per liter.

\section{Measurement of SOD activity}

SOD activity was measured using a Superoxide Dismutase Assay kit from Cayman Chemical Company, which uses a colorimetric assay to measure the concentration of formazan crystals. This assay uses a tetrazolium salt for the detection of superoxide radicals generated by xanthine oxidase and hypoxanthine. After treatment, the medium was removed from the wells, the adherent cells were scraped off and suspended in $20 \mathrm{mM}$ HEPES buffer, $\mathrm{pH}$ 7.2, containing $1 \mathrm{mM}$ EGTA, $210 \mathrm{mM}$ mannitol, and $70 \mathrm{mM}$ sucrose), sonicated, and placed on ice. To measure SOD activity, the diluted radical detector and the supernatant of lysed cells or standard were added to each well of a 96-well plate, and xanthine oxidase was added. Absorbance in the well was measured at a wavelength of $460 \mathrm{~nm}$ after $20 \mathrm{~min}$ on a microplate reader. The results are expressed as $\mathrm{IU} / \mathrm{mL}$.

\section{Measurement of lipid peroxidation}

The concentration of MDA, the end product of lipid peroxidation, was measured using a thiobarbituric acid 
reactive substance (TBARS) Assay kit from Cayman Chemical Company. After treatment, the medium was removed from the wells, adherent cells were scraped off, suspended in cold PBS, sonicated, and placed on ice. The supernatant from lysed cells or standard, sodium dodecyl sulfate, and the color reagent were added to each vial. The vial was heated at $100{ }^{\circ} \mathrm{C}$ for $1 \mathrm{~h}$ and then immediately cooled in an ice bath and centrifuged. The content of each vial was transferred to a well in a microplate. The absorbance of the product was measured at a wavelength of $540 \mathrm{~nm}$ on a microplate reader. The extent of lipid peroxidation was quantified by estimating the MDA concentration. The results are expressed as micromoles of MDA equivalents formed per liter.

\section{Statistical analysis}

The half-maximal inhibitory concentration $\left(\mathrm{IC}_{50}\right)$ values were calculated by regression analysis. The results are expressed as mean \pm standard deviation (SD). The data were analyzed using one-way analysis of variance (ANOVA) followed by Dunnett's multiple-comparison test using Prism software (v. 6.0; GraphPad, San Diego, CA, USA). Differences between means were considered significant at $P<0.05$.

\section{Results}

\section{DPPH radical-scavenging activity}

The DPPH radical-scavenging activity of SLM, SLB, and SLP was evaluated. The $\mathrm{IC}_{50}$ values were $39.71 \pm$ $0.85 \mu \mathrm{g} / \mathrm{mL}, 14.14 \pm 0.65 \mu \mathrm{g} / \mathrm{mL}$, and $169.53 \pm 2.19 \mu \mathrm{g} /$ $\mathrm{mL}$, respectively. Quercetin (used as a positive reference) scavenged DPPH radicals completely, and its $\mathrm{IC}_{50}$ value was $2 \mu \mathrm{g} / \mathrm{mL}$.

\section{$\mathrm{CCl}_{4}$-induced toxicity in HepG2 cells}

The toxic effects of $\mathrm{CCl}_{4}$ were time and concentration dependent (Fig. 1). Compared with the vehicle control, there were significant differences in cell viability; AST, ALT, and LDH activities; lipid peroxidation; TAOxC; and SOD and GSH levels. These differences remained significant up to an exposure time of $3 \mathrm{~h}(P<0.01)$.

\section{APAP-induced toxicity in HepG2 cells}

The toxic effects of APAP are shown in Fig. 2. The release of AST, ALT, and LDH increased during the first $12 \mathrm{~h}$ in HepG2 cells exposed to APAP, after which it declined; at $72 \mathrm{~h}$, the effect was not related to time or concentration. TAOxC and SOD and GSH concentrations, and cell viability decreased and MDA concentration increased in a dose- and time-dependent manner. These changes remained significant up to an exposure time of $72 \mathrm{~h}(P<0.01)$.

\section{Effects of SLM, SLB, and SLP in HepG2 cells}

The cytotoxic effects of SLM, SLB, and SLP on HepG2 cells exposed for $12 \mathrm{~h}$ are shown in Fig. 3. The compounds were considered to be toxic if there was a $>60 \%$ decrease in cell viability compared with untreated cells, an AST level $>50 \mathrm{IU} / \mathrm{L}$, ALT level $>30 \mathrm{IU} / \mathrm{L}$, TAOxC $>2 \mathrm{mM}$, or an MDA, SOD, or GSH concentration greater than that of the control (criteria established previously) [25]. According to these definitions, the compounds were not considered cytotoxic and were used to evaluate hepatoprotective activity.

\section{In vitro hepatoprotective effects}

The hepatoprotective effects of SLM, SLB, and SLP on HepG2 cells are shown in Fig. 4. HepG2 cells were pretreated with a hepatoprotective agent and subsequently exposed to $\mathrm{CCl}_{4}$ to induce damage. Only SLB at a concentration of $100 \mu \mathrm{g} / \mathrm{mL}$ or $150 \mu \mathrm{g} / \mathrm{mL}$ significantly decreased the levels of AST, LDH, and MDA, and prevented depletion of TAOxC compared with $\mathrm{CCl}_{4}(P$ $<0.01)$. Pretreatment with SLM at 10 or $100 \mu \mathrm{g} / \mathrm{mL}$ and SLP at any concentration did not prevent the reduction in TAOxC compared with $\mathrm{CCl}_{4}$. Pretreatment with SLM only at $150 \mu \mathrm{g} / \mathrm{mL}$ reduced the enzyme levels compared with $\mathrm{CCl}_{4}(P<0.01)$.

\section{Discussion}

In this study, we used the HepG2 cell line to evaluate the hepatoprotective activity of SLM, SLB, and SLP against liver damage induced by APAP and $\mathrm{CCl}_{4}$ in an attempt to establish a simple strategy for monitoring the hepatoprotective activities of plant extracts without high-end and excessive testing.

Cells exposed to these toxic agents lose cell viability, release liver enzymes into the culture medium, do not metabolize the tetrazolium salt, and exhibit significantly changed TAOxC and levels of MDA, SOD, and GSH $[16,26]$. The in vitro liver damage caused by $\mathrm{CCl}_{4}$ has been hypothesized to be caused by two different mechanisms, depending on the concentration used and the exposure time: a direct solvent effect of the molecule itself or an indirect effect through the generation of free radicals and subsequent lipid peroxidation [27].

Berger et al. studied the induction of cell membrane damage in isolated rat hepatocytes during the first 10 $30 \mathrm{~min}$ of exposure to $20 \% \mathrm{CCl}_{4}$ in ethanol by quantifying the MDA level as a marker of lipid peroxidation [28]. They postulated that these changes were caused by the direct action of the solvent, which affected the cell membrane, and that such changes are not preventable by antioxidant treatment within the initial $30 \mathrm{~min}$ of exposure. In the current study, $\mathrm{CCl}_{4}$ did not cause toxic effects or increase MDA level within $30 \mathrm{~min}$, but effects were seen at $60 \mathrm{~min}$; this observation seems to exclude any direct solvent effect. Holden et al. reported that the 

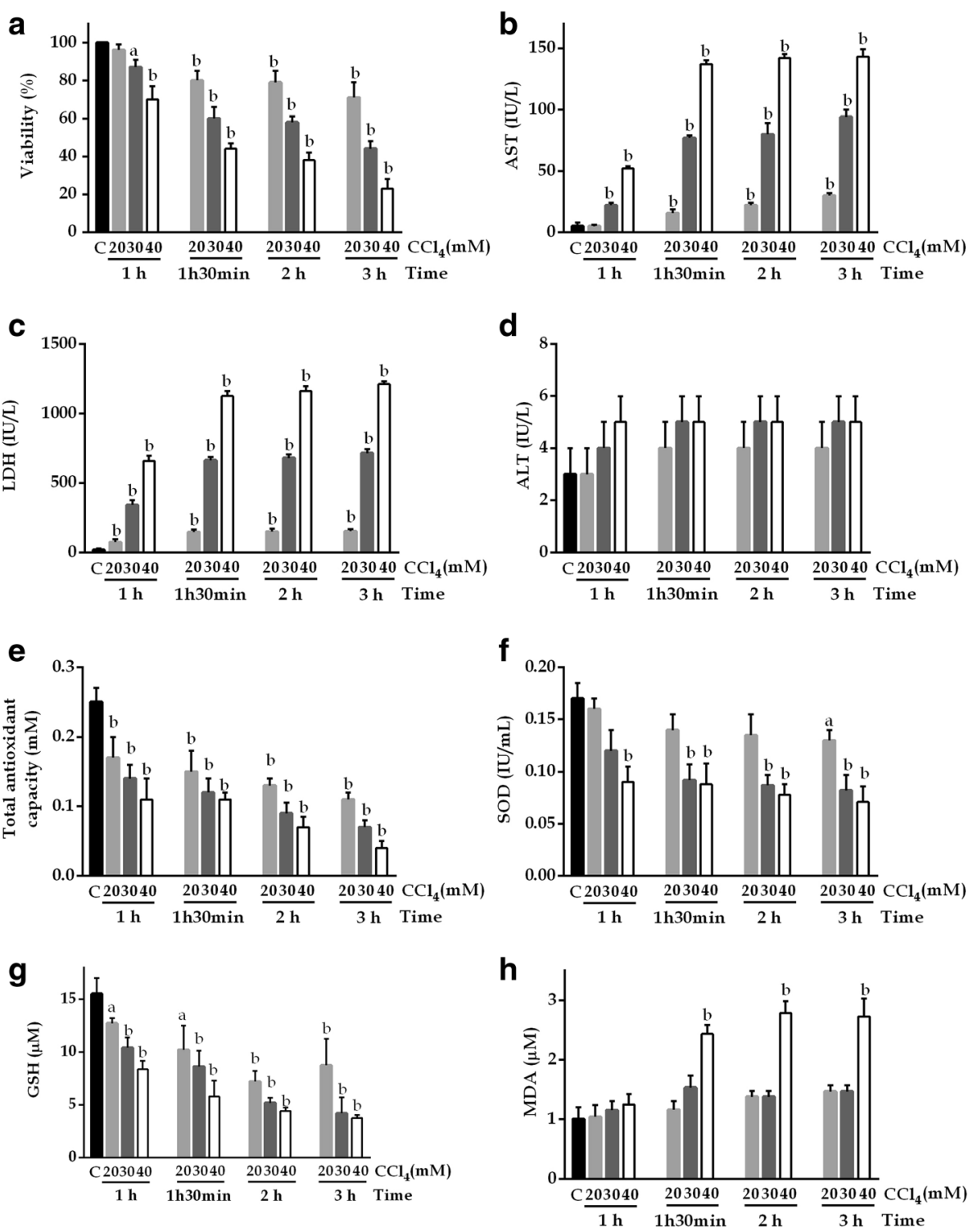

Fig. 1 Time-dependent changes in HepG2 cells. a Cell viability, b AST, $\mathbf{c} L D H, \mathbf{d} A L T$, e TAOxC, f SOD, $\mathbf{g}$ GSH, and h MDA levels after exposure to 20, 30, or $40 \mathrm{mM} \mathrm{CCl}_{4}$. Control: DMSO (0.05\% v/v) in supplemented DMEMA; $C C_{4} 20 \mathrm{mM}: 1.92 \mu \mathrm{L}$ of CCl $/ \mathrm{DMSO}(0.05 \% \mathrm{v} / \mathrm{v})$ in supplemented DMEMA; $\mathrm{CCl}_{4} 30 \mathrm{mM}: 2.88 \mu \mathrm{L}$ of CCl$/ \mathrm{DMSO}(0.05 \% \mathrm{v} / \mathrm{v})$ in supplemented DMEMA; $\mathrm{CCl}_{4} 40 \mathrm{mM}: 3.84 \mu \mathrm{L}$ of CCl$/ 4 \mathrm{DMSO}(0.05 \% \mathrm{v} / \mathrm{v})$ in supplemented DMEMA. Values are the mean \pm SD of three independent experiments performed in triplicate. ${ }^{a} P<0.05$ vs $C_{;}{ }^{b} P<0.01$ vs $C$

toxic effect of $\mathrm{CCl}_{4}$ at a concentration of $0.18 \%$ in $\mathrm{HepG} 2$ cells, as measured by release of LDH into the culture medium, increased significantly beginning at $1.5 \mathrm{~h}$ and LDH increased the release by up to $50 \%$ [26]. In our study, compared with control cells, HepG2 cells exposed to $\mathrm{CCl}_{4}$ exhibited a similar LDH response at $1.5 \mathrm{~h}$.

One study found significant participation of lipid peroxidation in the toxic effects via formation of free radicals and loss of viability in these cells after exposure to $0.5 \% \mathrm{CCl}_{4}$ for $2 \mathrm{~h}$ [16]. We found that, compared with control cells, HepG2 cells exposed to $\mathrm{CCl}_{4}$ showed significantly reduced viability, reduced TAOxC and GSH and SOD levels, and increased AST, LDH, and MDA activities at $1.5 \mathrm{~h}$. ALT activity did not change significantly, although this lack of change may relate to the timing of exposure to the toxic agent because previous studies have shown time-dependent increments in ALT activity [6, 7].

Oxidative stress also plays a major role in APAP toxicity. Oxidative stress occurs when the generation of reactive oxygen species overwhelms the ability to detoxify the reactive intermediates or exceeds the capacity to repair the 

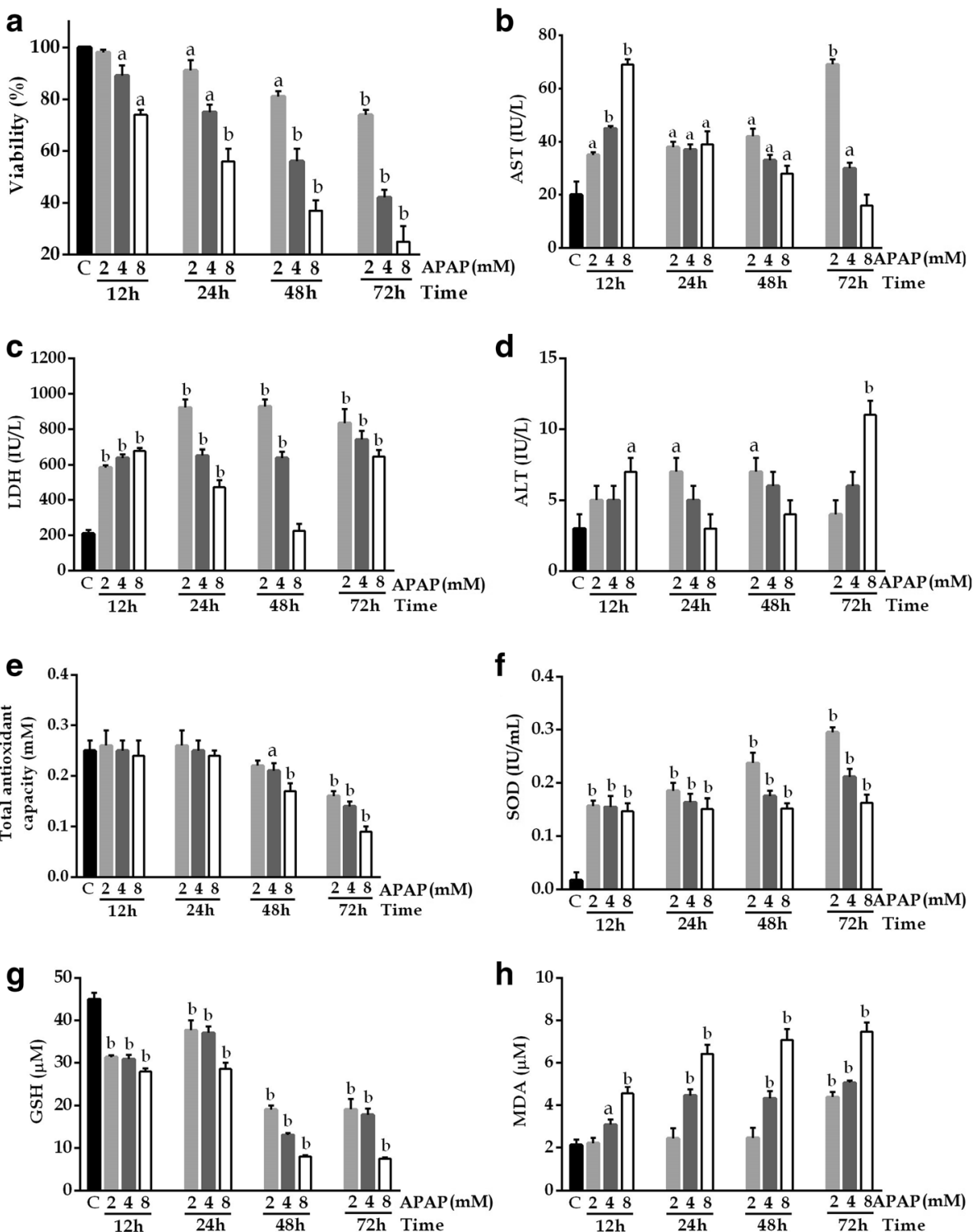

Fig. 2 Changes after exposure to 2, 4, or 8 mM APAP in HepG2 cells. a Cell viability, b AST, c LDH, d ALT, e TAOXC, f SOD, g GSH, and h MDA levels. Control: supplemented DMEMA; APAP 2 mM: $2 \mu \mathrm{L}$ in supplemented DMEMA; APAP 4 mM: $4 \mu \mathrm{L}$ in supplemented DMEMA; APAP 8 mM: $8 \mu \mathrm{L}$ in supplemented DMEMA. Values are the mean \pm SD of three independent experiments performed in triplicate. ${ }^{a} P<0.05$ vs $C$; ${ }^{b} P<.01$ vs $C$

resulting damage [29]. It has been reported that high APAP levels cause injury and reduce viability by up to $80 \%$ at $24 \mathrm{~h}$ [30]. In our study, HepG2 cells exposed to APAP showed similar results, and cell death was greatest after the longest exposure time $(72 \mathrm{~h})$. In other studies, HepG2 cells were exposed to serial concentrations of APAP for 24 and $72 \mathrm{~h}$, and LDH release increased with a dose of $10 \mathrm{mM}$ [31]. By contrast, in our study, increases in AST, ALT, and LDH release were evident only during the first $12 \mathrm{~h}$. However, the decreases in the TAOxC and SOD and GSH levels, and the increase in MDA level were time dependent throughout the observation period. HepG2 cells are killed by APAP [32, 33], but the mechanism causing death differs between HepG2 cells and cells that form a reactive metabolite, which causes apoptosis. For this reason, GSH depletion does not occur in HepG2 cells at $12 \mathrm{~h}$ [34], and our finding that GSH started to decrease only after $12 \mathrm{~h}$ is consistent with this observation. Because of the variability of the results obtained with APAP, the best inducer of cell injury in our study was $\mathrm{CCl}_{4}$ after $1.5 \mathrm{~h}$ incubation and at a concentration of $40 \mathrm{mM}$. Experimental results using various mediators 

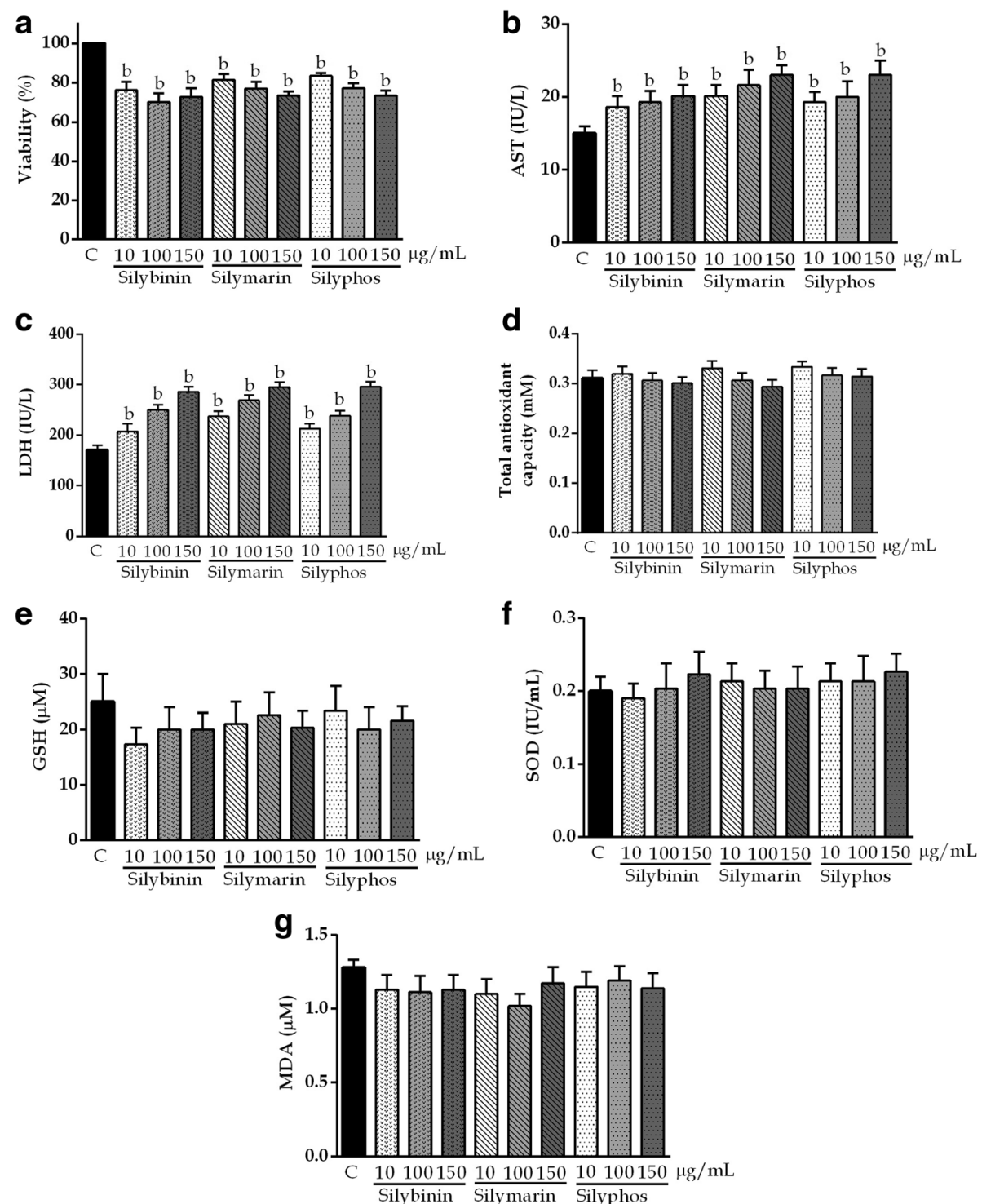

Fig. 3 Effects of silybinin, silymarin, and silyphos at concentrations of 10, 100, and $150 \mu \mathrm{g} / \mathrm{mL}$ for $12 \mathrm{~h}$ in HepG2 cells. The values are the mean \pm SD. ${ }^{a} P<0.05$ vs $C ;{ }^{b} P<0.01$ vs $C$

of oxidative stress confirm the involvement of free radicals acting through lipid peroxidation, as reported for this toxic agent $[6,7,16,26,28]$.

The hepatoprotective effects of $S$. marianum are due mainly to its antioxidant content. The DPPH assay is based on the reduction of the stable DPPH radical to a yellow diphenyl picryl hydrazine, which is a common spectrophotometric method for measuring the antioxidant capacity of compounds. Thus, the ability of SLM, SLB, and SLP to quench this radical is a measure of antioxidative activity. In this assay, the antioxidative activity was greater for SLB than for SLM, and for SLM than for SLP. The lower activity of SLP might relate to interactions between the different substances in the compound evaluated (Medix). The antioxidative activities of SLB and SLM that we observed are in agreement with previous research, which has reported strong DPPH free radical-scavenging activity for these compounds [35, 36].

Before evaluating the hepatoprotective activity of the various concentrations of SLM, SLB, and SLP, it was necessary to demonstrate that they are nontoxic. These compounds were not cytotoxic according to the definition of toxicity as a $>60 \%$ decrease in cell viability compared with untreated cells, AST level $<50$ IU/L, ALT level $<30 \mathrm{IU} / \mathrm{L}, \mathrm{TAOxC}<2 \mathrm{mM}$ or MDA, SOD, or GSH level 

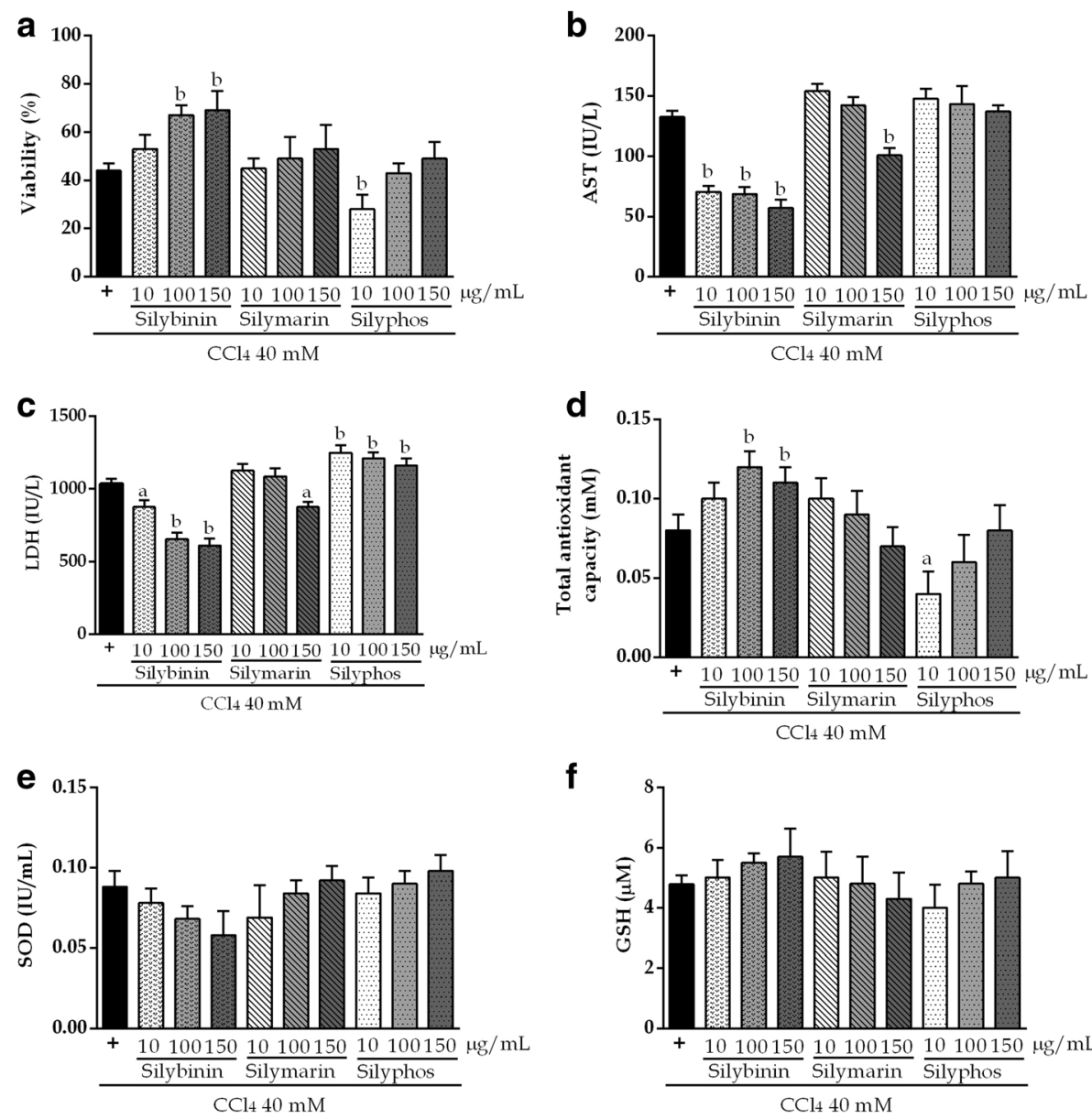

f
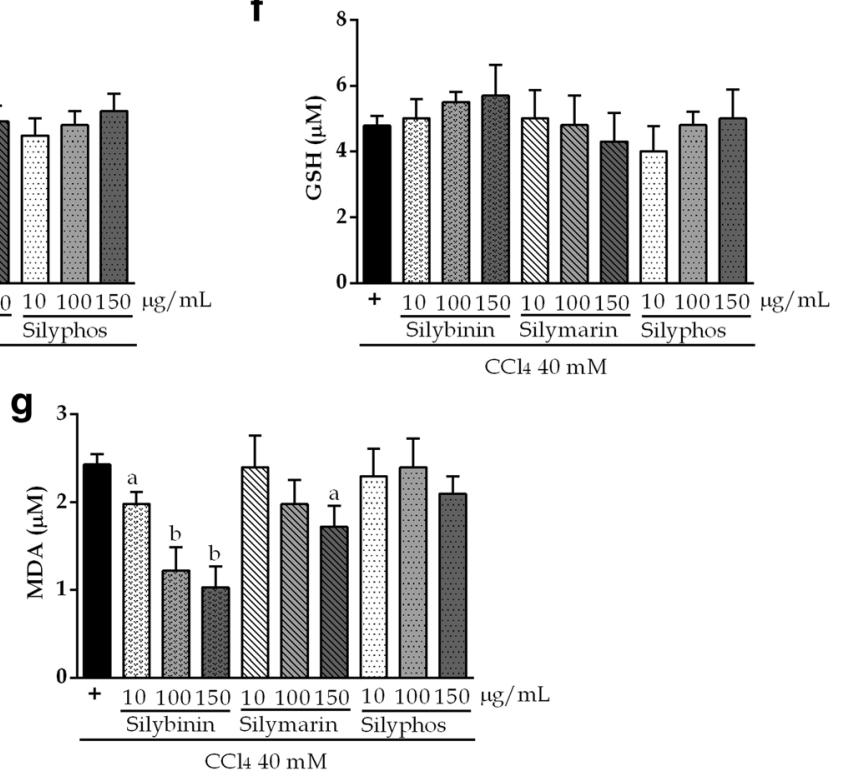

Fig. 4 Hepatoprotective effects of silybinin, silymarin, and silyphos against damage induced by $40 \mathrm{mM} \mathrm{CCl}{ }_{4}$ for $1.5 \mathrm{~h}$ in HepG2 cells. The values are the mean $\pm \mathrm{SD}$. ${ }^{a} P<0.05$ vs $\mathrm{CCl}_{4} ;{ }^{b} P<0.01{\mathrm{vs} \mathrm{CCl}_{4}}$

less than that of the control [25]. This finding is in agreement with those of previous studies [35-37].

We evaluated the hepatoprotective activities of SLM, SLB, and SLP against $\mathrm{CCl}_{4}$-induced liver damage at a dose of $40 \mathrm{mM}$ for $1.5 \mathrm{~h}$. In other in vivo models, $S$. marianum was reported to increase GSH level and to decrease MDA level, and SLB was shown to be the major biologically active component of SLM [12, 38, 39]. We found that pretreatment with SLB at the highest doses prevented the biochemical alterations indicative of damage induced by $\mathrm{CCl}_{4}$, although SLM did not have significant effects on cell viability at any of the doses studied.

It is important to mention that one way of indirectly assessing the damage to HepG2 cells caused by free radicals is by measuring the activities of intracellular enzymes (e.g., GSH, SOD) and TBARS, and the viability of cultured cells using the MTT assay. These measurements are useful for assessing the in vitro antioxidative actions of the hepatoprotective plant extracts [25, 40-43]. However, it has been proposed that other isolated active compounds in addition to those mentioned above should be included when 
evaluating the intracellular formation of reactive oxygen species, mitochondrial membrane potential, and changes in cell nuclei morphology in in vitro models. However, the use of all of these compounds may not be practical for routine testing because of the high cost of their inclusion in the monitoring of the hepatoprotective activities of all plant extracts [44-47].

\section{Conclusion}

The findings from this study show that $\mathrm{CCl}_{4}$ was a better injury inducer than APAP when used with $1.5 \mathrm{~h}$ incubation and at a concentration of $40 \mathrm{mM}$. SLB at a dose of $150 \mu \mathrm{g} / \mathrm{mL}$ was an adequate positive control for studying hepatoprotection. AST, LDH, and MDA were good markers of liver damage in HepG2 cells.

\section{Abbreviations}

ABTS: 2,2'-azino-bis-3-ethylbenzothiazoline; ALT: Alanine aminotransferase; APAP: Acetaminophen; AST: Aspartate aminotransferase; $\mathrm{CCl}_{4}$ : Carbon tetrachloride; DMEM-advanced: Dulbecco's modified Eagle's medium advanced; DMSO: Dimethyl sulfoxide; DPPH: 2,2-diphenyl-1-picrylhydrazyl free radical; DTNB: 5,5'-dithiobis-2-(nitrobenzoic acid): GSH: Reduced glutathione; HepG2: Human hepatoma cell line; IC 50 : Half-maximal inhibitory concentration; IU: International unit; LDH: Lactate dehydrogenase; MDA: Malondialdehyde; MTT: 3-(4,5-dimethylthiazol-2-yl)-2,5-diphenyl-2H-tetrazolium bromide; NAPQI: $\mathrm{N}$-acetyl-P-benzoquinoneimine; $\mathrm{nm}$ : Nanometer; PBS: Phosphate-buffered saline; SD: Standard deviation; SLB: Silybinin; SLM: Silymarin; SLP: Silyphos;

SOD: Superoxide dismutase; TAOxC: Total antioxidant capacity

\section{Acknowledgements}

We are profoundly grateful to staff at the School of Medicine and the University Hospital "Dr. José E. González" for the Universidad Autónoma de Nuevo León for their technical support.

\section{Funding}

This project was financially supported by CONACYT Convocatoria Científica Básica 2012, No. 180977

\section{Availability of data and materials}

The datasets supporting the conclusions of this article are included within the article.

\section{Authors' contributions}

TGL designed the study, acquired, analyzed, and interpreted the data, wrote the article, made critical revisions, and gave final approval of the version to be published. WMN designed the study, analyzed and interpreted the data, drafted the article, and made critical revisions. MELE designed the study, analyzed and interpreted the data, drafted the article, and made critical revisions. SAR analyzed and interpreted the data, drafted the article, and made critical revisions. PMJ analyzed and interpreted the data, drafted the article, and made critical revisions. CPP conceptualized and designed the study, acquired, analyzed, and interpreted the data, wrote the article, made critical revisions, and gave final approval of the version to be published.

\section{Competing interests}

The authors declare that there are no conflicts of interest.

\section{Consent for publication}

Not applicable.

\section{Ethics approval and consent to participate}

Not applicable.

\section{Author details}

'Liver Unit, Gastroenterology Service, Department of Internal Medicine, University Hospital "Dr. José E. González", Av. Gonzalitos \#235 Col. Mitras Centro C.P., 64460 Monterrey, Nuevo León, Mexico. ${ }^{2}$ Department of
Analytical Chemistry, School of Medicine, Universidad Autónoma de Nuevo León, Av. Madero y Aguirre Pequeño S/N, Col. Mitras Centro, C. P., 64460 Monterrey, N. L., Mexico.

Received: 25 May 2016 Accepted: 30 November 2016

Published online: 13 January 2017

\section{References}

1. Phillipson JD. Phytochemistry and medicinal plants. Phytochemistry. 2001;56:237-43

2. Duthie SJ, Melvin WT, Burke MD. Bromobenzene detoxification in the human liver-derived HepG2 cell line. Xenobiotica. 1994;24:265-79.

3. Conover CA, Lee PD. Insulin regulation of insulin-like growth factor-binding protein production in cultured HepG2 cells. J Clin Endocrinol Metab. 1990; 70:1062-7.

4. Sassa S, Sugita O, Galbraith RA, Kappas A. Drug metabolism by the human hepatoma cell, Hep G2. Biochem Biophys Res Commun. 1987;143:52-7.

5. Bouma ME, Rogier E, Verthier N, Labarre C, Feldmann G. Further cellular investigation of the human hepatoblastoma-derived cell line HepG2: Morphology and immunocytochemical studies of hepatic-secreted proteins. In Vitro Cell Dev Biol. 1989;25:267-75.

6. Pareek A, Godavarthi A, Issarani R, Nagori BP. Antioxidant and hepatoprotective activity of Fagonia schweinfurthii (Hadidi) Hadidi extract in carbon tetrachloride induced hepatotoxicity in HepG2 cell line and rats. J Ethnopharmacol. 2013; 150:973-81.

7. Krithika R, Mohankumar R, Verma RJ, Shrivastav PS, Mohamad IL, Gunasekaran P, Narasimhan S. Isolation, characterization and antioxidative effect of phyllanthin against $\mathrm{CCl}_{4}$-induced toxicity in HepG2 cell line. Chem Biol Interact. 2009;181:351-8.

8. Pradeep K, Mohan CV, Gobianand K, Karthikeyan S. Silymarin modulates the oxidant-antioxidant imbalance during diethylnitrosamine induced oxidative stress in rats. Eur J Pharmacol. 2007:560:110-6.

9. Rainone F. Milk thistle. Am Fam Physician. 2005;72:1285-8.

10. Lucena Ml, Andrade RJ, de la Cruz JP, Rodriquez-Mendizabal M, Blanco E, Sánchez de la Cuesta F. Effects of silymarin MZ-80 on oxidative stress in patients with alcoholic cirrhosis. Results of a randomized, double-blind, placebo-controlled clinical study. Int J Clin Pharmacol Ther. 2002;40:2-8.

11. Montvale NJ. Milk thistle (Silybum marianum) in PDR for Herbal Medicines. Med Econom Comp. Lewiston: 4th Edition by Thomson Healthcare; 2000. p. $516-20$

12. Kren V, Walterová $\mathrm{D}$. Silybin and silymarin —new effects and applications. Biomed Pap Med Fac Univ Palacký Olomouc Czech Repub. 2005;149:29-41.

13. Fraschini F, Demartini G, Esposti D. Pharmacology of silymarin. Clin Drug Investig. 2002;22:51-65.

14. Buzzelli G, Moscarella S, Giusti A, Duchini A, Marena C, Lampertico M. A pilot study on the liver protective effect of silybin-phosphatidylcholine complex (IdB1016) in chronic active hepatitis. Int J Clin Pharmacol Ther Toxicol. 1993; 31:456-60.

15. Barzaghi N, Crema F, Gatti G, Pifferi G, Perucca E. Pharmacokinetic studies on IdB 1016, a silybin-phosphatidylcholine complex, in healthy human subjects. Eur J Drug Metab Pharmacokinet. 1990;15:333-8.

16. Harries HM, Fletcher ST, Duggan CM, Baker VA. The use of genomics technology to investigate gene expression changes in cultured human liver cells. Toxicol In Vitro. 2001;15:399-405.

17. Bajt ML, Knight TR, Lemasters JJ, Jaeschke H. Acetaminophen-induced oxidant stress and cell injury in cultured mouse hepatocytes: protection by $\mathrm{N}$-acetyl cysteine. Toxicol Sci. 2004;80:343-9.

18. Rivera CA, Bradford BU, Hunt KJ, Adachi Y, Schrum LW, Koop DR, Burchardt ER, Rippe RA, Thurman RG. Attenuation of $\mathrm{CCl}_{4}$-induced hepatic fibrosis by GdCl3 treatment or dietary glycine. Am J Physiol Gastrointest Liver Physiol. 2001;281:G200-7.

19. Ingawale DK, Mandlik SK, Naik SR. Models of hepatotoxicity and the underlying cellular, biochemical and immunological mechanism(s): a critical discussion. Environ Toxicol Pharmacol. 2014:37:118-33.

20. Pattern CJ, Thomas PE, Guy RL, Lee M, Gonzalez FJ, Guergerich FP, Yang CS. Cytochrome P450 enzymes involved in acetaminophen activation by rat and human liver microsomes and their kinetics. Chem Res Toxicol. 1993;6:511-8.

21. Nelson SD. Molecular mechanisms of the hepatotoxicity caused by acetaminophen. Semin Liver Dis. 1990;10:267-78.

22. Holownia A, Braszko JJ. Acetaminophen alters microsomal ryanodine $\mathrm{Ca}^{2+}$ channel in HepG2 cells overexpressing CYP2E1. Biochem Pharmacol. 2004; 68:513-21. 
23. Salazar-Aranda R, Pérez-López LA, López-Arroyo J, Alanís-Garza BA, Waskman de Torres N. Antimicrobial and antioxidant activities of plants from northeast of Mexico. Evid Based Complement Alternat Med. 2011;2011:536139.

24. Mosmann T. Rapid colorimetric assay for cellular growth and survival: application to proliferation and cytotoxicity assays. J Immunol Methods. 1983;65:55-63.

25. Torres-González L, Muñoz-Espinosa LE, Rivas-Estilla AM, Trujillo-Murillo K, Salazar-Aranda R, Waksman De Torres N, Cordero-Pérez P. Protective effect of four Mexican plants against $\mathrm{CCl}_{4}$-induced damage on the Huh7 human hepatoma cell line. Ann Hepatol. 2011;10:73-9.

26. Holden PR, James NH, Brooks AN, Roberts RA, Kimber I, Pennie WD. Identification of a possible association between carbon tetrachloride-induced hepatotoxicity and interleukin-8 expression. J Biochem Mol Toxicol. 2000;14:283-90.

27. Chen S, Morimoto S, Tamatani M, Fukuo K, Nakahashi T, Nishibe A, Jiang B, Ogihara T. Calcitonin prevents CCl4-induced hydroperoxide generation and cytotoxicity possibly through $\mathrm{C} 1 \mathrm{~b}$ receptor in rat hepatocytes. Biochem Biophys Res Commun. 1996;218:865-71.

28. Berger $\mathrm{ML}$, Bhatt $\mathrm{H}$, Combres $\mathrm{B}$, Estabrook RW. $\mathrm{CCl}_{4}$-induced toxicity in isolated hepatocytes: the importance of direct solvent injury. Hepatology. 1986;6:36-45.

29. Cover C, Mansouri A, Knight TR, Bajt ML, Lemasters JJ, Pessayre D, Jaeschke $H$. Peroxynitrite-induced mitochondrial and endonuclease-mediated nuclear DNA damage in acetaminophen hepatotoxicity. J Pharmacol Exp Ther. 2005; 315:879-87.

30. Lin J, Schyschka L, Muhl-Bennighaus R, Neumann J, Hao L, Nussler N, Dooley S, Liu L, Stockle U, Nussler AR, Ehnert S. Comparative analysis of phase I and II enzymes activities in 5 hepatic cells lines identifies Huh-7 and HCC-T cells with highest potential to study drug metabolism. Arch Toxicol. 2012;86:87-95

31. Jian J, Briedé JJ, Jennen DG, Van Summeren A, Saritas-Brauers K, Schaart G, Kleinjans JC, de Kok TM. Increased mitochondrial ROS formation by acetaminophen in human hepatic cells is associated with gene expression changes suggesting disruption of the mitochondrial electron transport chain. Toxicol Lett. 2015;234:139-50.

32. Macanas-Pirard P, Yaacob NS, Lee PC, Holder JC, Hinton RH, Kass GE. Glycogen synthase kinase-3 mediates acetaminophen-induced apoptosis in human hepatoma cells. J Pharmacol Exp Ther. 2005;313:780-9.

33. Manov I, Hirsh M, lanuc TC. N-acetylcysteine does not protect HepG2 cells against acetaminophen-induced apoptosis. Basic Clin Pharmacol Toxicol. 2004:94:213-25.

34. McGill MR, Williams CD, Xie $Y$, Ramachandran A, Jaeschke $H$. Acetaminophen-induced liver injury in rats and mice: comparison of protein adduct, mitochondrial dysfunction, and oxidative stress in the mechanism toxicity. Toxicol Appl Pharmacol. 2002;264:387-94.

35. De Oliveira DR, Schaffer LF, Busanello A, Barbosa CP, Peroza LR, De Freitas CM, Krum BN, Bressan GN, Boligon AA, Athayde ML, De Menezes AIR, Fachinetto R. Silymarin has antioxidant potential and changes the activity of $\mathrm{Na}+/ \mathrm{K}+$ -ATPase and monoamine oxidase in vitro. Ind Crop Prod. 2015;70:347-55.

36. Gazák R, Purchartová K, Marhol P, Zivná L, Sedmera P, Valentová K, Kato N, Matsumura H, Kaihatsu K, Kren V. Antioxidant and antiviral activities of silybin fatty acid conjugates. Eur J Med Chem. 2010;45:1059-67.

37. Cardile AP, Mbuy GKN. Anti-herpes virus activity of silibinin, the primary active component of Silybum marianum. J Herb Med. 2013;3:132-6.

38. Nencini C, Giorgi G, Micheli L. Protective effect of silymarin on oxidative stress in rat brain. Phytomedicine. 2007;14:129-35.

39. Valenzuela A, Aspillaga M, Vial S, Guerra R. Selectivity of silymarin on the increase of the glutathione content in different tissues of the rat. Planta Med. 1989;55:420-2.

40. Ghaffari H, Venkataramana M, Navaka SC, Ghassam BJ, Angaswamy N, Shekar S, Sampath Kumara KK, Prakash HS. Hepatoprotective action of Orthosiphon diffusus (Benth.) methanol active fraction through antioxidant mechanisms: an in vivo and in vitro evaluation. J Ethnopharmacol. 2013;149:737-44.

41. Pamplona S, Sá P, Lopes D, Costa E, Yamada E, e Silva C, Arruda M, Souza J, da Silva M. In vitro cytoprotective effects and antioxidant capacity of phenolic compounds from the leaves of Swietenia macrophylla. Molecules. 2015;20(10):18777-88

42. Liu JP, Feng L, Zhu MM, Wang RS, Zhang MH, Hu SY, Jia XB, Wu JJ. The in vitro protective effects of curcumin and demethoxycurcumin in Curcuma longa extract on advanced glycation end products-induced mesangial cell apoptosis and oxidative stress. Planta Med. 2012;78(16):1757-60.

43. Mersch-Sundermann V, Knasmüller S, Wu XJ, Darroudi F, Kassie F. Use of a human-derived liver cell line for the detection of cytoprotective, antigenotoxic and cogenotoxic agents. Toxicology. 2004;198:329-40.
44. Parikh H, Pandita N, Khanna A. Phytoextract of Indian mustard seeds acts by suppressing the generation of ROS against acetaminopheninduced hepatotoxicity in HepG2 cells. Pharm Biol. 2015;53:975-84.

45. Zhang R, Zhao Y, Sun Y, Lu X, Yang X. Isolation, characterization, and hepatoprotective effects of the raffinose family oligosaccharides from Rehmannia glutinosa Libosch. J Agric Food Chem. 2013;61(32):7786-93.

46. Pourahmad J, Eskandari MR, Shakibaei R, Kamalinejad M. A search for hepatoprotective activity of fruit extract of Mangifera indica L. against oxidative stress cytotoxicity. Plant Foods Hum Nutr. 2010;65(1):83-9.

47. Su D, Zhang R, Zhang C, Huang F, Xiao J, Deng Y, Wei Z, Zhang Y, Chi J, Zhang M. Phenolic-rich lychee (Litchi chinensis Sonn.) pulp extracts offer hepatoprotection against restraint stress-induced liver injury in mice by modulating mitochondrial dysfunction. Food Funct. 2016;7(1):508-15.

\section{Submit your next manuscript to BioMed Central and we will help you at every step:}

- We accept pre-submission inquiries

- Our selector tool helps you to find the most relevant journal

- We provide round the clock customer support

- Convenient online submission

- Thorough peer review

- Inclusion in PubMed and all major indexing services

- Maximum visibility for your research

Submit your manuscript at www.biomedcentral.com/submit
Biomed Central 